\title{
既往の実験報告に基づく鋼構造梁端接合部の力学性能に関する研究 A STUDY ON CHARACTERISTICS OF STEEL BEAM-TO-COLUMN CONNECTIONS BASED ON REPORTED TEST RESULTS
}

\author{
山崎真司*, 見波 進**, 張宏***, 香林 洋**** \\ Shinji YAMAZAKI, Susumu MINAMI, Hong ZHANG \\ and Hiroshi KORIN
}

\begin{abstract}
Primary factors, which have an influence upon the maximum strength of beam-to-column connections, were investigated based on the test results reported in papers. The relationship between the test conditions and the maximum strength for 263 specimens was studied. It was found that the maximum strength of connections for fast loading and/or in low temperature can be estimated using the same method as that for static loading in room temperature in consideration of a variation in yield point and tensile strength caused by strain rate and/or temperature. The conditions in which the maximum stress of beam flange is nearly equal to or exceeds the tensile strength of coupon tests were investigated.
\end{abstract}

Keywords : Beam-to-column connection, Maximum bending strength, Ultimate strength ratio 柱梁接合部, 最大曲げ耐力, 最大強度上昇率

1. 序

1994 年のノースリッジ地震, 1995 年の兵庫県南部地震において, 鋼構造骨組柱梁接合部に扔ける破断現象が数多く発生した. 本研究 は既往の研究 1) 31) に報告されている実験結果に基づき鋼構造耐震 骨組梁端接合部の力学性能に関して, 耐震設計に資する情報を提供 することを目的とする.

梁材の塑性エネルギー吸収は, 主に材端から塑性化の程度に応じ て順次中央に向かって拡大する梁部材の塑性化領域によって行われ る. 塑性化領域の拡大は材端モーメントの上昇を伴う. 従って, 梁 端接合部には部材の塑性化領域の拡大を可能にする耐力が必要であ る.

終局限界状態に対する梁端接合部の設計は, 基本的には当該部材 に要求される変形能力(エネルギー吸収能力)に基づき接合部の必要 耐力が設定され, 接合部の保有する耐力がこの必要耐力以上である ことを確認することにより行われると考えられる. 現在の耐震規定 では梁端の塑性化領域長について標準的な值が想定され，これに基 づき材端接合部の必要耐力の標準值がいわゆる保有耐力接合条件と して示されている．接合部の形状等を限定すれば接合部の設計を変 形能力を直接の指標として行うことも考えられるが, 多様な柱梁断 面の組合せに対する適用性を考慮すれば，接合部設計で用いる直接 の指標は耐力であると考えられる。

梁端接合部の力学性能に関しては既に多くの実験的研究が行われ
ている.これらの研究において, 接合部の力学性能は殆どの場合変 形能力(エネルギー吸収能力)で評価されている，筆者等は次の理由 で耐力指標による評価も必要であると考える．部材のエネルギー吸 収能力, 言い換えれば接合部耐力の部材全塑性モーメントからの上 昇には, 鋼材の降伏比, フランジ最大強度上昇率(最大曲げ耐力に 達したときのフランジ平均軸方向応力度とフランジ材の引張強さの 比), ウェブ部分の継手効率等が関係する. 変形能力指標を用いる ことにより，接合部の総合的な評価を行うことは可能であるが，こ れら個々の要因に対する分析を行うことは一般に困難である．既往 の文献において，フランジが脆性破断した実験結果が数多く報告さ れているが，多くの文献ではフランジ最大強度上昇率についての検 討結果が示されていない，たとえば，最大強度上昇率が1以上であ れば, 脆性破断であっても溶接部を含むフランジ端部の基本性能は 確保されていると判断される。このとき十分な変形能力が得られて いないのであれば，その主な原因はフランジ端部強度以外にある. この様に, 力学性能に係わる個々の要因について検討を行うことは 接合部の力学的性能を明確にする上で重要であると考える。また， 接合部の設計を耐力指標で行うことを前提とすれば，実験結果を耐 力に関する指標で整理する必要があると考える.

本研究は既往の多数の実験結果を, 耐力に関する共通の指標で整 理し，終局限界状態に対する接合部設計に有用な資料を提供しよう とするものである.

\footnotetext{
* 東京都立大学大学院工学研究科建築学専攻 教授・工博

** 東京都立大学大学院工学研究科建築学専攻 助手・博士 (工学)

*** 巴コーポレーション 修士(工学)

(元東京都立大学 大学院生)

*****東京都立大学大学院工学研究科建築学専攻 修士課程
}

Prof., Dept. of Architecture, Graduate School of Engineering, Tokyo Metropolitan Univ., Dr. Eng.

Research Assoc., Dept. of Architecture, Graduate School of Engineering, Tokyo Metropolitan Univ., Dr. Eng.

Tomoe Corporation, M. Eng.

Graduate Student, Dept. of Architecture, Graduate School of Engineering, Tokyo Metropolitan Univ. 


\section{2. 梁端接合部の力学性能}

\section{1 性能指標}

地震時に経験する様な繰返し履歴を受ける梁の弾塑性挙動は一方 向載荷時の挙動と対応づけられることが知られている.すなわち, 繰返し載荷時の荷重変形関係から求めたスケルトン曲線は一方向載 荷時の荷重変形関係と対応する。

梁の限界耐力は座屈(局部座屈, 横座屈)あるいは接合部の破断に よって決る. 本研究では限界耐力が梁端接合部の破断で決る場合を 検討対象とする.

破断で限界づけられる梁端接合部の最大モーメント $\mathrm{M}_{\max }$, ある いはその無次元表示であり次式で定義される最大耐力保数 $\alpha$ は, 後 に述べる特殊な場合を除いて繰返し載荷時と一方向載荷時で概ね等 しい值となる。

$$
\alpha=\frac{M_{\max }}{M_{p}}
$$

ここで, $\mathbf{M}_{\max }$ : 梁端接合部の最大曲げ耐力

$$
\mathbf{M}_{\mathrm{p}}: \text { 梁母材の全塑性モーメント }
$$

梁材の塑性エネルギー吸収は，そのほとんどが梁端近傍の塑性化 した梁母材でなされる。梁端接合部に要求される性能は, 塑性領域 を確保するために必要な耐力であると捉え，本研究では(1)式の $\alpha$ を 梁端接合部の力学的性能を表す指標とする.

既往の実験における載荷は, 振動台実験の場合を除いて子め決め られた載荷プログラムによって行われている. 載荷プログラムは一 方向載荷, 漸増振幅繰返し載荷, 一定振幅繰返し載荷に大別される.

繰返し載荷プログラムの例を図1に示す，漸増振幅繰返し載荷で は, 一定振幅で1３回程度の繰返しを行いつつ順次振幅を増加させ ている。この様な繰返し載荷時の $\alpha$ は一方向載荷時の $\alpha$ と概ね対応 する.

一方，一定振幅繰返し載荷実験では， 変位振幅を一定(変位振幅の大きさは $\pm 3 \delta_{\mathrm{p}}$ $\sim \pm 5 \delta_{\mathrm{p}}$ 程度, $\delta_{\mathrm{p}}$ : 降伏変位)に保って数 10 回の繰返しを行い破断に至らしめてい る. (数10回の一定振幅で破断しない場合 は更に振幅を増加させて繰返し載荷を行 い破断に至らしめている。)この様な絽返 し載荷時の $\alpha$ は多くの場合, 一方向載荷 時の $\alpha$ より低い值である. 地震応答では 最大振幅付近での繰返し数は数回程度で あり, 一定振幅綝返し載荷実験の様な状

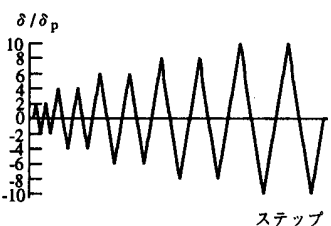

（a）潥增振幅繰返し

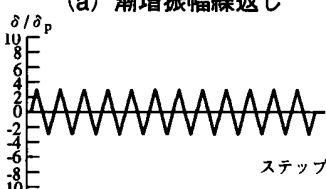

(b) 一定振幅繰返し

図1＼cjkstart載荷プログラムの例 況で限界状態に至ることは無いと考えられる(2.2参照). 従って，一 定振幅繰返し載荷実験から得られる $\alpha$ は耐震設計で用いるには適当 で無いと判断する.

また, フランジが早期に(平均応力度が鋼材の引張強さに対して かなり低い值で)脆性破断する場合にも，一方向載荷時の $\alpha$ と絽返 し載荷時の $\alpha$ は対応しない場合があると考えられる．梁の塑性エネ ルギー吸収を期待した耐震設計を行う場合, フランジは早期に脆性 破断しないことが接合部設計の前提であると考えられる。本研究で は，フランジが早期に脆性破断することを避ける条件については考 察するが，この様な破断が生じるときの $\alpha$ の評価法については検討 の対象外とする。
以上より, 本研究では既往の実験報告の中で, 一方向載荷, 漸増 繰返し載荷および振動台実験を行った試験体を対象として，梁端接 合部の最大曲げ耐力について検討する.

\section{2 最大耐力係数とエネルギー吸収能力}

材端最大モーメントとエネルギー吸収量とは密接な関係がある.

一方向載荷の場合, 最大耐力係数と塑性変形倍率の関係は文献 32)に基づき, 理論的に求めることが出来る ${ }^{33)}$. 繰返し載荷の場合, 最大耐力係数と累積塑性変形倍率の関係は載荷履歷の影響を受ける. 地震応答時の最大耐力係数と累積塑性変形倍率の関係は, 梁中間荷 重の影響も考慮して概略推定することが出来る ${ }^{33)}$.

\section{3 検討方法}

梁端接合部の最大曲げ耐力 $\mathbf{M}_{\max }$ を次式で表す.

$$
M_{\max }=Z_{\mathrm{pf}} \cdot \sigma_{\mathrm{f} \max }+\mathrm{M}_{\mathrm{w}}
$$

ここで, $\sigma_{\mathrm{f} \text { max }}$ :接合部が最大曲げ耐力に達したときのフランジの平 均軸方向応力度

$\mathrm{Z}_{\mathrm{pf}}$ :フランジ断面による塑性断面係数

$\mathbf{M}_{\mathbf{w}}$ : 最大曲げ耐力時にウェプで伝達されるモーメント

$\sigma_{\mathrm{f} \text { max }}$ は, 応力集中注1), 端部の歪拘束等の影響で材の引張強さ以 上となる場合，あるいは歪集中部からの亀裂発生・成長により引張 強さ以下になる場合があると考えられる。

$\sigma_{\mathrm{f} \max }$ についての検討は, 次式で定義される最大強度上昇率 $\beta$ を 用いて行j。

$$
\beta=\frac{\sigma_{\mathrm{f} \max }}{\sigma_{\mathrm{uf}}}
$$

ここで, $\sigma_{\mathrm{uf}}:$ フランジ材の引張強さ

ところで, 実験より得られる值は $M_{\max }$ であり， $\sigma_{\mathrm{f} \max }$ は実験結 果より直接求めることが出来ない，本研究では， $\mathrm{M}_{\mathrm{w}}$ を文献34)に基 づき推定し，推定した $\mathrm{M}_{\mathrm{w}}$ と実験結果による $\mathrm{M}_{\max }$ を(2)式に代入し て $\sigma_{\mathrm{f} \max }$ を求めることとする。本研究における $\mathrm{M}_{\mathrm{w}}$ の算定法を 付録1に示す．最大耐力係数 $\alpha$ は， $\beta$ を用いて次式で表される.

$$
\alpha=\frac{\beta \sigma_{\mathrm{uf}} Z_{\mathrm{pf}}+\mathrm{M}_{\mathrm{w}}}{\mathrm{M}_{\mathrm{p}}}
$$

\section{4 歪速度・温度の影響}

梁端接合部の性能に及ほす歪速度・温度の影響を調べることを 目的として，高速載荷実験または低温下での実験あるいはそれら を同時に考慮した実験が行われている。これらの実験において素 材の降伏点, 引張強さは, 歪速度・温度により変化するので $\alpha, \beta$ の算定の際には, 歪速度・温度の影響を考慮した降伏点, 引張強 さを用いなければならない。

一部の文献を除いて使用鋼材の機械的性質に及ほす歪速度・温度 の影響についての資料は報告されていない，本研究では，文献35) に基づき，下式により降伏点 $\sigma_{\mathrm{y}}$, 引張強さ $\sigma_{\mathrm{u}}$ を推定した

40 キロ鋼の場合： $\sigma_{\mathrm{y}} / \sigma_{\mathrm{y} 0}=0.66 \exp (3570 / \mathrm{R})$

50 キ口鋼の場合 : $\sigma_{\mathrm{y}} / \sigma_{\mathrm{y} 0}=0.72 \exp (2425 / \mathrm{R})$

$$
\sigma_{\mathrm{u}} / \sigma_{\mathrm{u} 0}=0.79 \exp (1573 / \mathrm{R})
$$

ここで, $\sigma_{\mathrm{y}}, \sigma_{\mathrm{u}}$ : 歪速度・温度を考慮した降伏点, 引張強さ $\sigma_{\mathrm{y} 0}, \sigma_{\mathrm{u} 0}:$ JIS弓張試験により得られる降伏点, 引張強さ $\mathrm{R}=\mathrm{T} \ln (\mathrm{A} / \dot{\varepsilon})$ : 歪速度・温度パラメーター ${ }^{36)}$ 


\section{3. 試験体一覧}

本研究では，文献1)～31)に報告されている試験体のうち，以下の i)〜vi)に該当するものを除いた試験体を検討対象とした。

i）一定振幅で多数回繰返し載荷を行っているもの（2.1参照）

ii）パネルゾーンの降伏が先行するもの

試験体の一部にパネルゾーンの降伏が先行するものがある，パネ ルゾーンの降伏が梁端接合部の限界耐力に及ほす影響についての 検討は今後の課題とし, 本研究ではパネルゾーンの降伏が先行す る場合を対象外とする. (付録2)

iii）梁材の降伏点, 引張強さが不明なもの

iv) 梁端仕口形状が特殊なもの(仕口部で梁フランジ幅を広げている もの, ウェブが接合されていないもの等)

v）フランジ突合せ溶接部に意図的に溶接欠陥を挿入したもの

vi）実験結果の耐力に疑問のあるもの

同一形状, 同一鋼材を用いたシリーズの実験結果で, 座届あるい は破断による低下が生じていないと考えられる載荷ステップの範 囲において，一部の試験体の荷重が明らかに低い場合が見られ $た^{19)}$.これら耐力に疑問のある試験体は対象外とした.

検討対象とした試験体は計263体である，試験体の一覧を表1に示 す. 表1の(a)〜 (m)の内容は以下である.

(a) 本論文で用いる試験体番号

(b) 文献番号

(c) 文献で用いられている試験体名

(d) 試験体形式（図2参照）

$\mathrm{X}$ : X型又は十字型, $\mathrm{T} ： \mathrm{~T}$ 型, $\mathrm{S}$ ：単純梁型, $\mathrm{C}$ ：片持梁型

(e) 柱断面形

H：H形断面, B : 箱形断面, P : 円形中空断面, 無印 : 柱無

(f) ウェブ接合方法

$\mathrm{W}$ : 溶接接合, $\mathrm{B}$ ：高力ボルト接合

(g) スカラップ

$\mathrm{S}$ : 従来型, $\mathrm{R}$ : 改良型, $\mathrm{N}$ ：ノンスカラップ

(h) 載荷

$\mathrm{M}$ ：一方向載荷, $\mathrm{C} ：$ 漸増振幅繰返し載荷

D：振動台実験

(i) 載荷速度

無印：静的載荷, $\bigcirc:$ 高速載荷

(j) 試験温度

無印 : 室温, $\triangle: 0^{\circ} \mathrm{C}, \mathrm{O}: 0^{\circ} \mathrm{C}$ 末満

(k) 破断状況

無印：載荷中に梁フランジ又はタイアフラムに破断が生じ ている. (以下では破断と呼ぶ)

$\bigcirc$ : 上記以外注2). (以下では未破断と呼ぶ)

(l) (1)式による $\alpha$ の值

(m) (3)式による $\beta$ の值

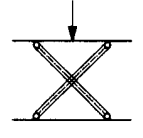

$\mathrm{X}$ 型

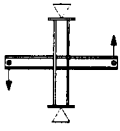

十字型

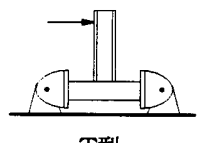

T型 図2

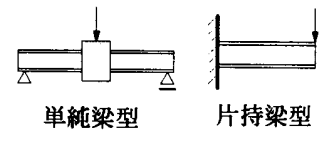

表 1 試験体一覧

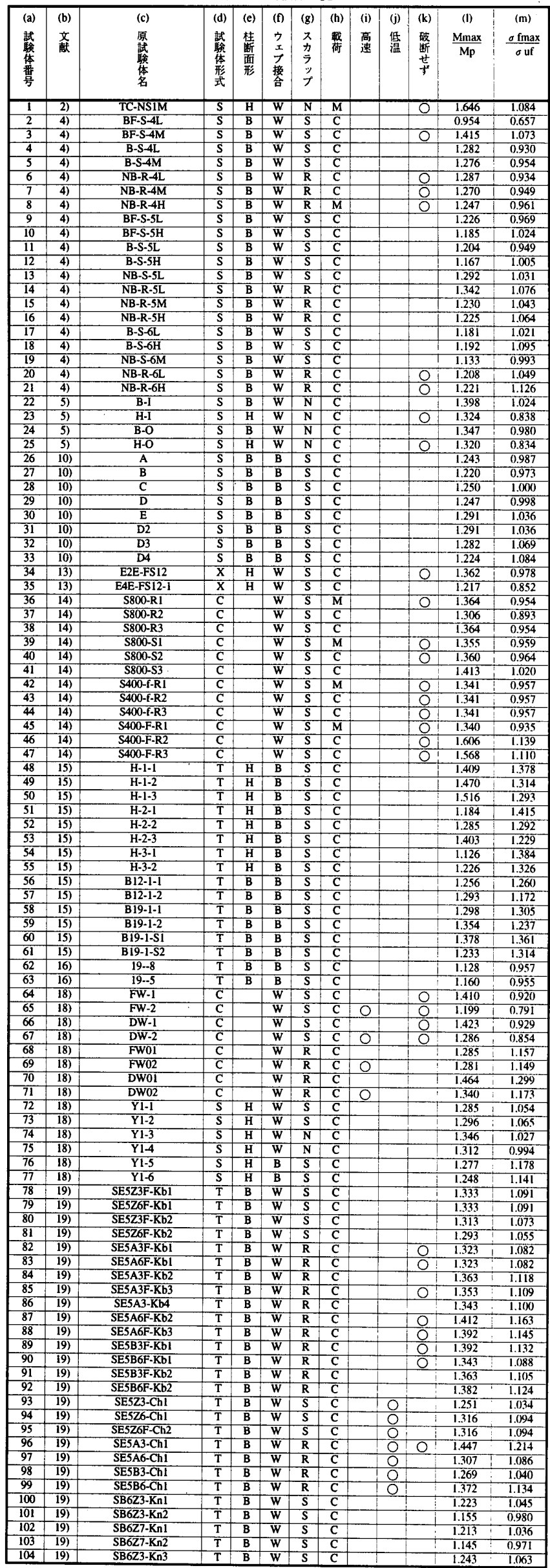




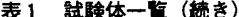

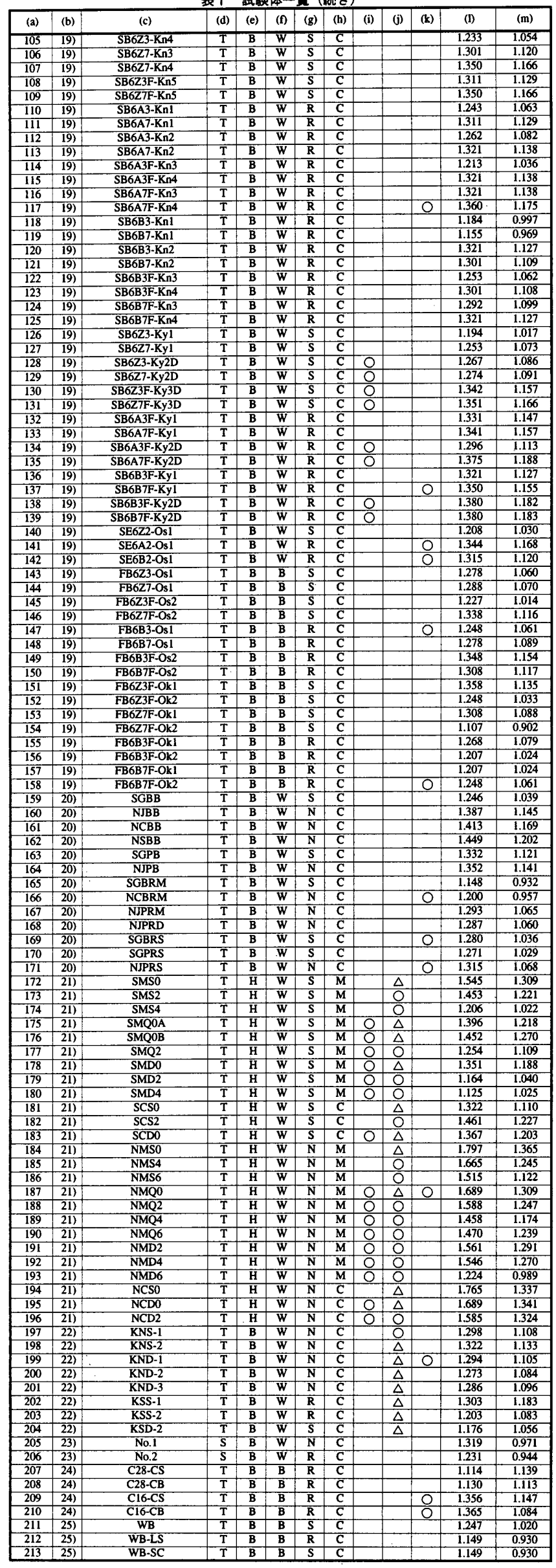
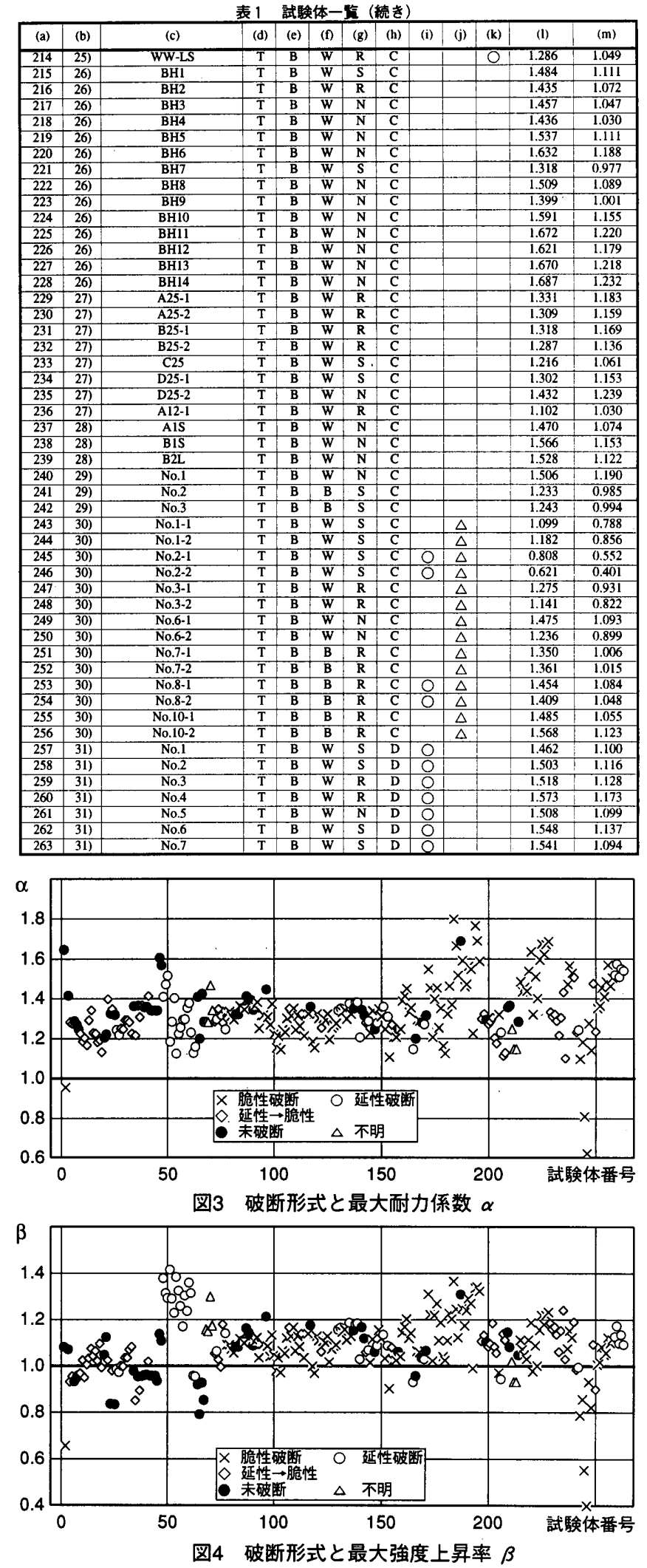

最大耐力値が記載されていない試験体の最大耐力は荷重変形関係 のグラフより読み取った。

耐力計算に用いた降伏点, 引張強さは, 素材試験結果が報告され ている場合はその結果を, 報告されていない場合は文献中に記載さ れているミルシート值を用いた。 また，柱が箱形断面材の場合で柱 材の降伏点が不明な場合は, 鋼材F値の1.1倍と仮定した注3). 

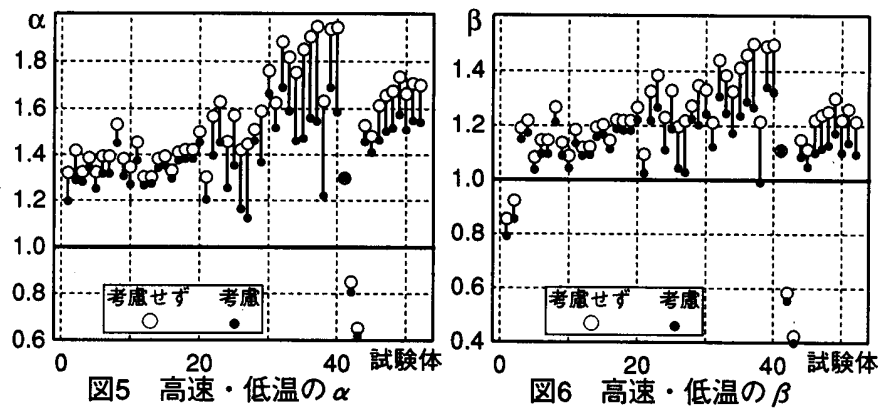

なお，未破断の試験体についても $\alpha, \beta$ を算出し, 以下の検討図にプ ロットしているが, これらは参考值 である。これらの值に対して試験体 か破断していないことを示している.

表1の全試験体について, $\alpha, \beta$ の值を実験で報告されている以下の 破断形式に区別して図3，4に示す。 横軸は表 1 の試験体番号である.

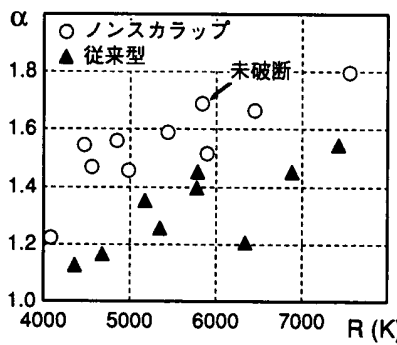

図7 $\mathrm{R}$ と $\alpha$ の関係

破断形式 延性破断：破断面の殆どが延性破面

脆性破断：破断面の殆どが脆性破面

延性一脆性破断：延性破面から脆性破面に移行

延性破断した試験体の $\beta$ は，全て1付近あるいは1以上である，脆 性破断した試験体の一部は $\beta$ が1に比べてかなり低い。これらの試 験体の塑性エネルギー吸収量はほとんど0かあるいは少ない，脆性 破断した試験体で， $\beta$ が1付近あるいは1以上のものも多くある。こ れらの $\beta$ は，延性破断した試験体の $\beta$ とほほ同程度の範囲に分布し ている，延性 $\rightarrow$ 脆性破断試験体の $\beta$ は，ほほ0.9〜12程度の範囲に 分布している。

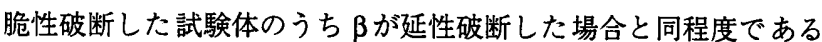
ものが高比率で存在している。これらの試験体については脆性破断 は生じているが, 溶接部を含むフランジ端部の基本的性能は確保さ れていると考えられる。

\section{4. 耐力に影響を及ぼすと考えられる諸要因に関する分析}

\section{1 昰速度・温度}

表1の試験体に扔ける高速載荷試験の速度範囲は, 加力点の変位 速度で2 $100 \mathrm{~cm} / \mathrm{s}$, 梁端フランジの歪硬化域の歪速度で0.0065 $0.71 / \mathrm{s}$ である. また, 低温時の実験における試験体温度の範囲は $00^{\circ} \mathrm{C}$ 〜-60Cである.

高速載荷試験および0 C末渵の低温試験を行っている計52体の試 験体については，2.4で述べた方法で歪速度・温度の影響を考慮し た降伏点, 引張強さを求め, これを用いて表 1 の， $\beta$ を算出して いる.

図5, 図6において, 上記の考慮をせず引張試験の結果より得られ た $\sigma_{\mathrm{y}}, \sigma_{\mathrm{u}}$ を用いて $\boldsymbol{\alpha}, \beta$ の值を評価した場合を○印で, 歪速度. 温度の影響の考慮した $\sigma_{\mathrm{y}} ， \sigma_{\mathrm{u}}$ を用いて評価した場合を○印でプロッ トしている，考慮の有無による $\alpha ， \beta$ 違いはかなり大きいことが 分かる，高速・低温試験の結果より $\alpha, \beta$ を評価する場合は, 歪速 度・温度の影響を考慮した降伏点, 引張強さを用いる必要がある。

図7は，文献21)の試験体を対象として静的載荷，室温時に対する
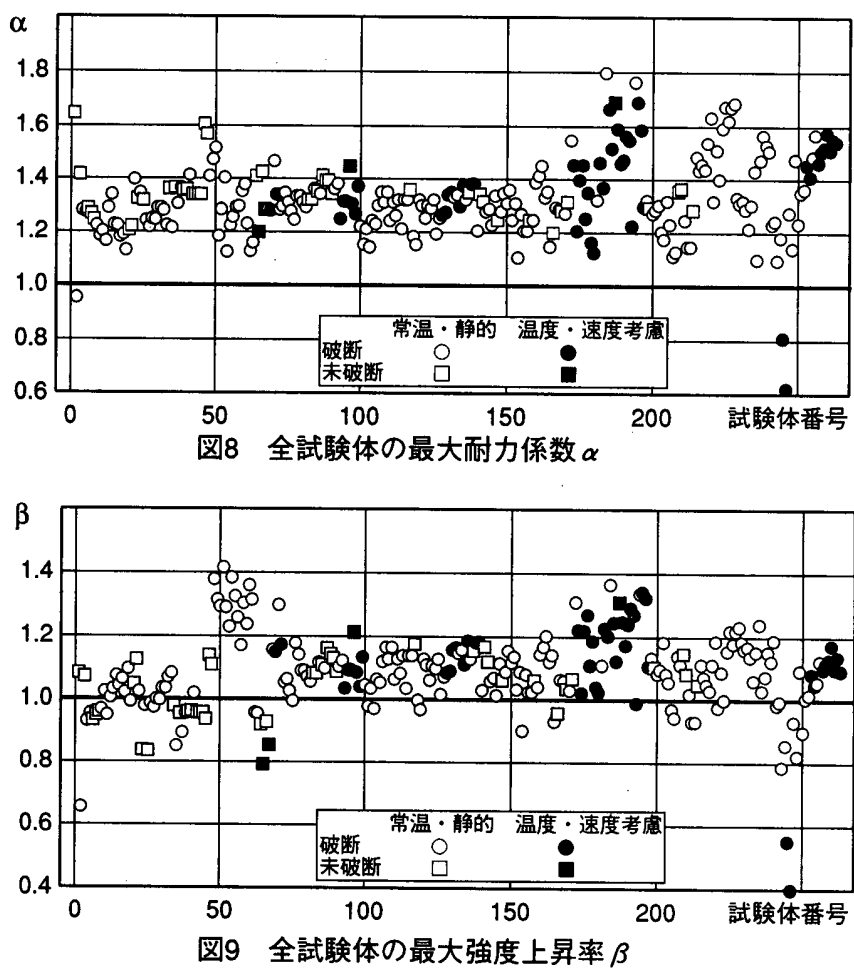

実験結果と, 載荷速度・温度以外は同一条件で速度あるいは温度の みを変えた実験結果に対する $\alpha$ の值を，(6)式による歪速度・温度パ ラメーターRを変数とし，プロットしたものである． $\alpha$ 算定にお いて, 歪速度・温度の影響を考慮した降伏点, 引張強さを用いてい る. 鋼材の性質として低温, 高速になる程(Rが小さくなる程)降伏 点, 引張強さ共に上昇する傾向があり，また，降伏点の上昇率が引 張強さの上昇率より大きい. 従って, 歪速度 ·温度以外が同一条件 の試験体については，Rが小さい程降伏比が大きくなり， $\alpha か ゙$ 小さ くなる傾向を示すことが予想される. 図7のプロットを見ると，Rと $\alpha$ の間には全体的に上述の傾向が窅える。 Rが最も小さいO印(ノン スカラップ)のプロットは $\alpha$ の低下がやや大きい， $\beta$ 值でみると, 他 の○印プロットに対する試験体の場合は1.12以上であるのに対し， Rが最も小さい試験体の場合は0.99である。この試験体については, 歪速度・温度が $\beta$ に若干影響を与えていることが予想されるが， $\beta$ の值はほほ1であり，その影響は顕著ではない。

図8，図9は，全試験体について，高速載荷あるいは低温試験を行っ ている試験体を区別して， $\alpha ， \beta$ 值をプロットしたものである.

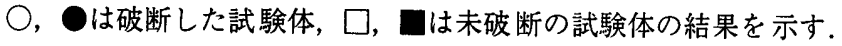

○, 口は高速載荷あるいは $0{ }^{\circ} \mathrm{C}$ 未満の低温試験を行っている試験体 である。

歪速度・温度が梁端接合部の曲け耐力に影響を及ぼす要因として, 高速・低温時の破壊勒性の変化が考えられる，図9を見ると，高速・ 低温条件下で破断した試験体の $\beta$ は，2体を除いて 1 以上であり，静 的常温載荷の場合の值と同程度の範囲に分布している。 ベてかなり低い2体の試験体は, シャルピー吸収エネルギーの值が 比較的小さく，かつ，表当金組立溶接を連続隅肉溶接としているも のである(4.4参照)．本研究で検討対象としている既往の実験結果の 範囲では，上記の場合を除けば，歪速度・温度による破壊勒性の変 化が $に$ 及ほす影響は顕著でないことが分かる。 


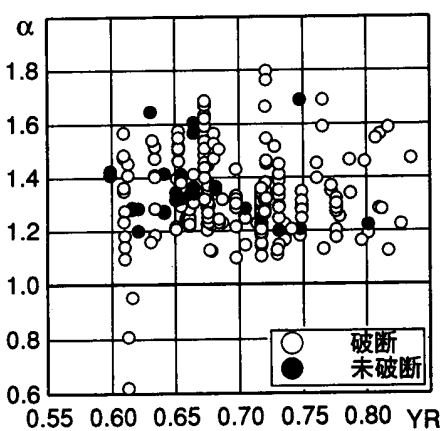

図10 フランジ材のYRと $\alpha$ の関係

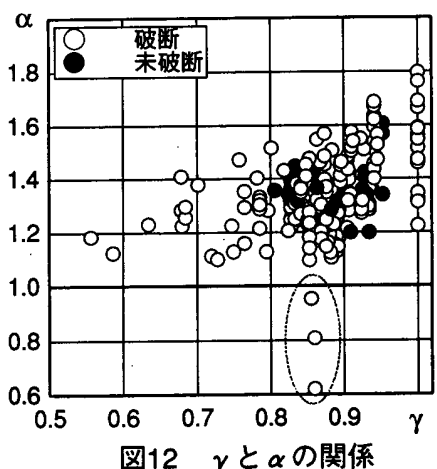

図12 $\gamma$ と $\alpha$ の関係

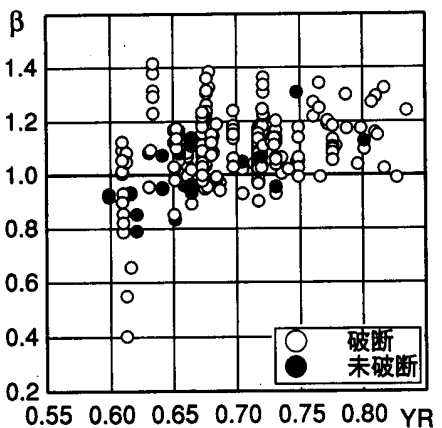

図11 フランジ材のYRと $\beta$ の関係

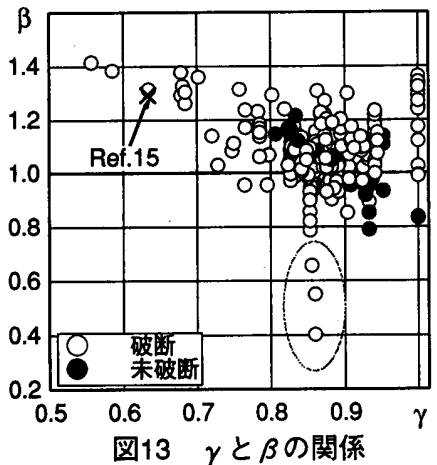

4.2 降伏比

フランジ材の降伏比YRと $\alpha, \beta$ との関係を図10, 図11に示す.

梁端接合部の継手効率(4.3参照)が1でかつ $\beta$ もであれば， $\alpha$ はR の逆数になる．継手効率は0.55〜1の範囲にあり，また，及のばらつ きも大きいことから，図10で，YRと $\alpha$ の相関は見られない.また 図11より，YRが小さい領域でのßのばらつきが大きいものの，全体 として $\beta$ に対するYRの影響は特に見られない.

\section{3 梁端接合部の継手効率}

梁端接合部の曲げ耐力に関する継手効率 $\gamma$ を次式で定義する.

$$
\begin{aligned}
& \gamma=\frac{M_{u j}}{M_{u}} \\
& M_{u}=Z_{p f} \cdot \sigma_{u f}+Z_{p w} \cdot \sigma_{u w} \\
& M_{u j}=Z_{p f} \cdot \sigma_{u f}+M_{w}
\end{aligned}
$$

ここで, $\mathrm{Z}_{\mathrm{pw}}$ : 梁ウェブ部分の塑性断面係数

$\sigma_{\mathrm{uw}}:$ 梁ウェブ材の引張強さ

$\gamma$ と $\alpha, \beta$ との関係を図12, 図13に示す.

図12より，早期に脆性破断した試験体(図中に点線で囲む)と未破 断の試験体を除くと， $\gamma$ と $\alpha$ とは予想される様に正の相関を有して おり， $\gamma$ を大くすることがエネルギー吸収能力を高める上で効果 がある.

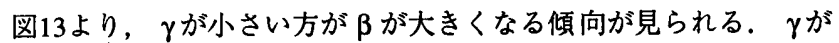
小さい程フランジ材端における応力集中度が高いことがその要因で あると考えられる注1).

図13の×印は，文献15)に報告されている材端でウェブを全く接 続していない片持梁試験体の実験結果より得られた してプロットしたものである、この $\beta$ 值は実験結果の最大耐力から 直接求められたものである．×印の $\beta$ 值は， X印近傍の他の実験結 果の $\beta$ 值と同程度の值であることが分かる.

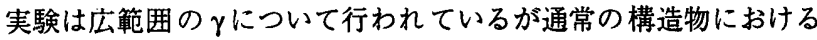
$\gamma$ は 075 程度以上である. $\gamma$ が 075 以上の試験体を対象とすると， $\beta$
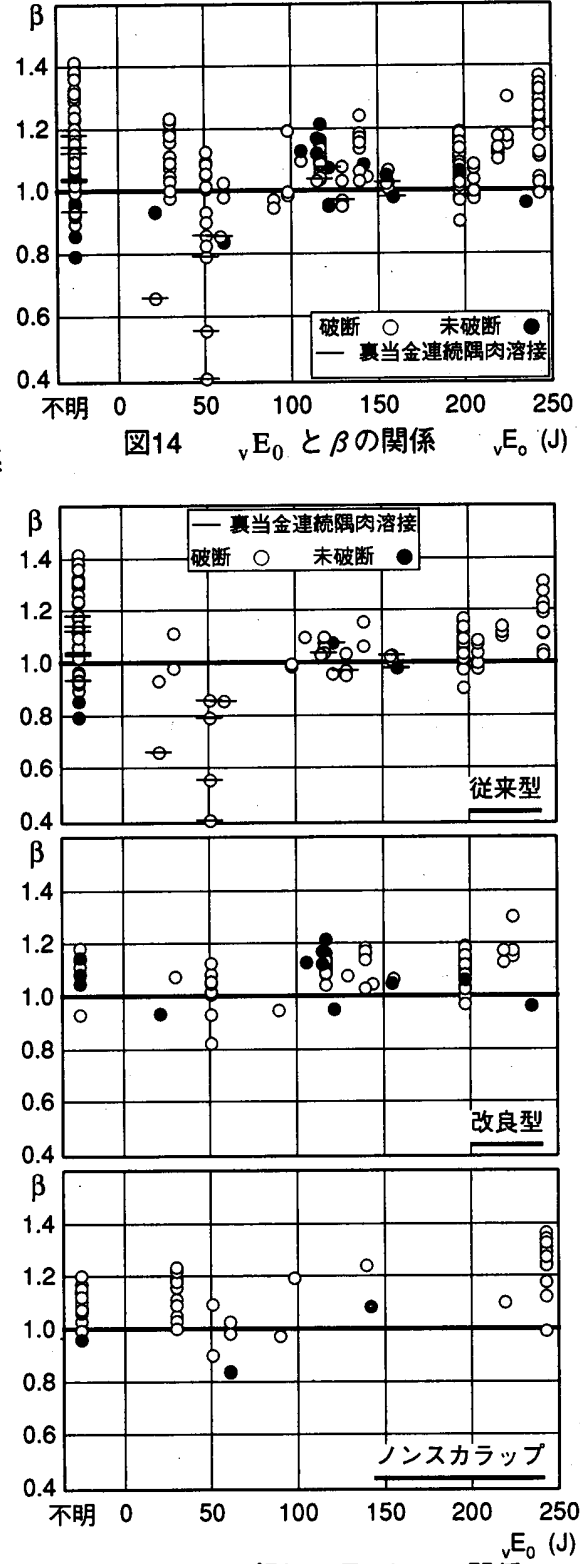

図15 スカラップ別の ${ }_{v} E_{0}$ と $\beta$ の関係

值が 0.96 と 1.22 の間 に試験体の $80 \%$ が分 布している.

4.4 シャルピー吸収 エネルギー, スカラッ $フ^{\circ}$

梁フランジ材の V ノッチシャルピー吸 収エネルギー $\left(0^{\circ} \mathrm{C}\right)$ ${ }_{\mathrm{v}} \mathrm{E}_{0}$ と $\beta$ の関係を図 14に示す．毫当金組 立溶接が㹴続隅肉溶 接(以下では連続隅肉 と記す)の場 合変形能 カが低下する（すな わち，最大耐力が低 下する）場合がある ことが知られている ので，該当するプロッ トに一印を付けた。

試験体の ${ }_{\mathrm{v}} \mathrm{E}_{0}$ は $21.6 \mathrm{~J} \sim 243 \mathrm{~J}$ の範囲に ある. ${ }_{\mathrm{v}} \mathrm{E}_{0}$ が90丁以上 のプロットについて みると, 連続隅肉の 場合も含めて, $\beta$ は 1 付近あるいは 1 以上 (概ね1以上)で， $\beta$ に 対する、笛 の影響は 小さいと考えられる. 一方 $\mathrm{E}_{0}$ が60J以下の プロットについてみ

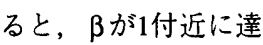
しないものがある.

図15は，図14のプロットをスカラップの型で分けて表示したもの である.

従来型スカラップの場合は, ${ }_{\mathrm{v}} \mathrm{E}_{0}$ が50J以下で連続隅肉の場合に, $\beta の か な り$ 低い試験体がある，連続隅肉でない破断試験体の $\beta$ は 0.9 以上である.

改良型スカラップでßの最も小さい試験体は，やや大きな溶接欠 陷(深さ $6 \mathrm{~mm}$ で幅7 $0 \mathrm{~mm}$ の未溶着部および深さ $7 \mathrm{~mm}$ で長さ $35 \mathrm{~mm}$ のス ラグ巻込部)を有しその箇所から脆性破断したもので, この試験体 のßが低い要因は溶接欠陥にあると考えられる。この試験体を除く と， $\beta$ は0.9以上である.

ノンスカラップの場合も, 破断試験体のßは全て0.9以上となって いる.

以上より，前記の溶接欠陥を有する試験体を除く破断試験体につ いて, ノンスカラップ工法, 改良型スカラップ工法および連続隅肉 としない従来型スカラップ工法の場合は $\beta$ 值は0.9以上であること， 従来型スカラップ工法で連続隅肉の場合は、 $\mathrm{E}_{0}$ がおよそ100J以上で 
あれば $\beta$ は 0.9 以上であることが分 かる. 現実の接合部では連続隅肉 以外にも局所的な歪集中や切欠き の発生が予想されるので, それら に起因する耐力低下を出来るだけ 避けるためには，、 $\mathrm{E}_{0}$ は100 J 程度 以上であることが望ましいと言え よう.

\section{5 乃が概ね1以上となる条件}

梁の塑性エネルギー吸収を期待 する場合はフランジが早期に脆性

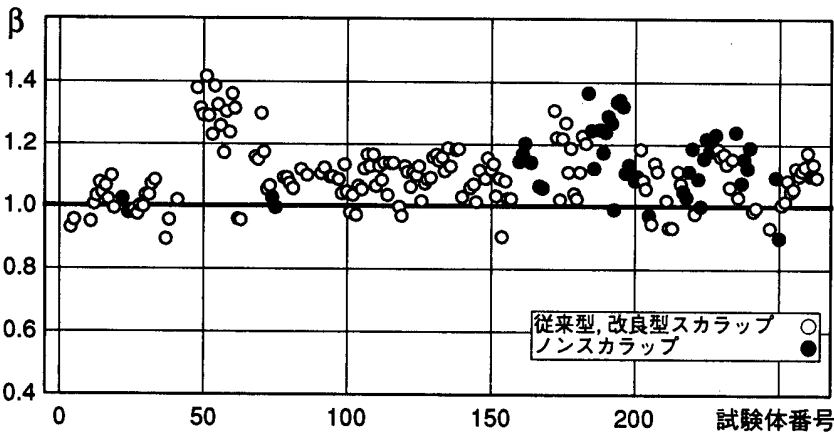

図16 連続隅肉を除く破断試験体の最大強度上昇率 $\beta$

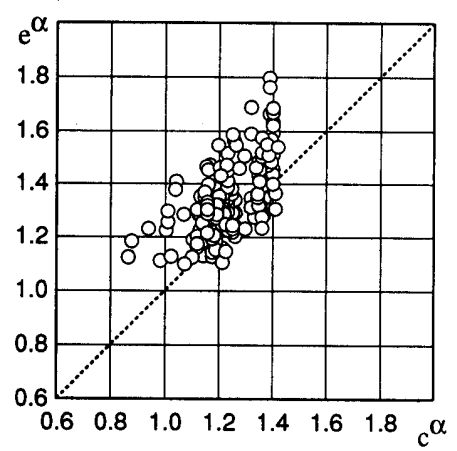

図17実験値と計算俥の $\alpha$
破断しないことが接合部設計の前提であると考えられるので (2.1)， $\beta$ が概ね1以上となる条件について考える。

従来型スカラップの場合で、 $\mathrm{E}_{0}$ が50J以下のとき，連続隅肉をし た試験体の中に $\beta$ がかり低い值で破断しているものがある， $\beta を$ 概ね1以上とするためには，連続隅肉としないことを条件とするこ とは妥当であろう。

連続隅肉試験体および前述の溶接欠陥を有する試験体を除くと, 破断試験体の $\beta$ は全て0.9以上である.

以上より，明らかな溶接欠陥を有する場合を除いた試験体につい ては，連続隅肉を避ければ、 $\mathrm{E}_{0}$ にかかわらず $\beta$ は概ね1以上である といえるが， ${ }_{v} \mathrm{E}_{0}$ が小さい実験シリーズが限られていることから， ${ }_{\mathrm{v}} \mathrm{E}_{0}$ についての条件は図 14 からは導き出せないと考えるべきであろ

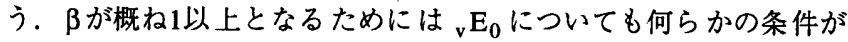
必要であると考えられるが，この条件を明らかにするためには実験 データの更なる蓄積が必要である.

\section{5. 最大耐力係数}

表当金組立溶接を連続隅肉溶接としているものおよび明らかな溶 接欠陥を有する試験体を除いた破断試験体の $\beta$ を図16に示す。 $\beta$ の 変動幅はやや大きいといえるが，ほとんどが1以上である，連続隅 肉を行わない場合を対象とすれば， $\beta$ を1として(4)式により最大耐 力係数 $\alpha$ を評価する方法が考えられる.

実験値の $\alpha\left({ }_{e} \alpha\right)$ と $\beta=1$ とした計算值の $\alpha\left({ }_{c} \alpha\right)$ の関係を図17に示 す．図17よりこの方法は多くの場合 $\alpha$ を安全側に評価することが分 かる．評価式の精度は必ずしも高いものではないが， $\mathbf{M}_{\mathbf{w}}$ の評価精 度，乃のばらつきを考えると, 現状では設計式として明解であると 考える。

\section{6. 結論}

既往の論文に報告されている実験結果に基づき，梁端接合部の力 学性能を耐力指標を用いて検討した. 最大耐力と全塑性モーメント の比を最大耐力係数 $\alpha$, 最大耐力に達したときのフランジ平均軸方 向応力度とフランジ材の引張強さの比を最大強度上昇率 $\beta$ とし, $\alpha, \beta$ を指標として実験結果に対する分析を行った，高速・低温載 荷試験の $\alpha, \beta$ は, 歪速度 ·温度による降伏点, 引張強さの変化を 考慮して算定した，本論文で得られた結論は以下の様にまとめられ る.

1）延性破断した試験体のßは概ね1以上である。脆性破断した試験 体については，一部の試験体で $\beta$ が1に比べかなり低いものもある
が， $\beta$ が延性破断した試験体と同程度であるものも多数ある.

2）フランジ材端の早期脆性破断を避け $\beta$ が概ね 1 以上となるための 条件のひとつは，襄当金組立溶接を連続隅肉溶接としないことで ある、シャルピー吸収エネルギーについての条件も必要であると 考えられるが，現状ではシャルピー吸収エネルギーの低い場合の 実験資料が不足しており十分な検討が出来ない，シャルピー吸収 エネルギーについての条件を明らかにすることは今後の課題であ る.

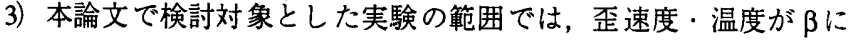
及は寸影響は顕著ではない。

4）鋼材のシャルピー吸収エネルギーが既往の実験に用いられた試 験体鋼材と同程度であることを前提とするとき，裏当金組立溶接 を連続隅肉溶接としなければ， $\alpha$ は次式において 安全側に評価することが出来る.

$\alpha=\left(\beta \sigma_{\mathrm{uf}} \mathrm{Z}_{\mathrm{pf}}+\mathrm{M}_{\mathrm{w}}\right) / \mathrm{M}_{\mathrm{p}}$

ここで， $\mathrm{M}_{\mathrm{w}}$ は付録 1 の方法で算出する.

謝辞 本研究にあたり，多くの貴重な実験結果を使用させていただ きました．文献の原著者の方々に深く感謝申し上げます。

\section{参考文献}

1）藤本盛久, 橋本篤秀, 中込忠男, 金鍾洛, 松村弘道：柱はり溶接接合部 の破壊特性の検討, 日本建築学会構造系論文報告集, 第349号, pp 81 $90,1985.3$

2) 中込忠男, 矢部喜堂, 坂本真一: 梁スカラップの有無が $\mathrm{H}$ 形断面柆に溶 接接合される $\mathrm{H}$ 形铜梁端部の力学的性状に及ほす影響, 日本建筑学会構 造系論文報告集，第432号，pp.51 -59, 1992.2

3）藤田哲也, 中込忠男, 水崎祐一：角形鋼管柱を用いた柱梁溶接接合部の 力学的性能に関する実験的研究, 日本建築学会大会学術講演梗概集, pp. $1537 \sim 1538,1992.8$

4) 山本昇, 石井匠, 森田耕次: はり端溶接接合部の力学的举動におよほす スカラップの影響，構造工学論文集, Vol.39B, pp.493－506，1993.3

5) 真喜志卓, 山本昇, 筒井茂行, 藤沢一善, 上森博, 石井匠, 森田耕次 ノンスカラップ梁端溶接接合部の変形能力に関する実験 その1一その 2 , 日本建築学会大会学術講演梗概集, pp.1257 1260, 1993.9

6）田渕基嗣，金谷弘，田中丈之, 園田隆一：角形鋼管柱・梁仕口溶接部に おける改良型スカラップ工法の提案，銅構造年次論文報告集，第1巻， pp.65 72, 1993.7

7) 中込忠男, 藤田哲也，田中一男，鳴沢明雄：現場溶接型柱梁溶接接合部 の力学的性能, 鋼構造年次論文報告集, 第 1 巻, pp.101 108, 1993.7

8) 坂本真一, 矢部喜堂, 真瀬伸治：現場溶接接合形式の柱梁接合部におけ る $\mathrm{H}$ 形鋼梁端部 $9 力$ 学的性能, 日本建築学会構造系論文集, 第456号, pp.69 79, 1994.2

9) 旦比野展, 吉野治行, 新藤忠徳：柱·梁溶接接合部に関する実験的研究, 日本建築学会大会学術講演梗概集, C1, pp.1461 1462, 1994.9

10）松尾世志浩, 寺岡勝, 森田耕次, 佐々木聡, 藤原敏夫：混用接合形式の 角形鋼管柱・H形鋼梁接合部における力学的挙動に与える接合部詳紐の 影響 その1〜その2, 日本建築学会大会学術講演梗概集, Cl, pp 1473 $1476,1994.9$

11) 坂本真一，矢部喜堂：現場溶接接合形式の柱梁接合部における梁端部の 曲け耐力, 鋼構造年次論文報告集, 第2巻, pp.337 - 344, 1994.11

12）田㴊基嗣，田中丈之, 濱名正洋：改良型スカラップエ法による通しダイ アフラム形式角形鋼管柱・梁仕口に関する研究, 鋼構造年次論文報告集, 
第2巻, pp.345 352, 1994.11

13) 藤本盛久, 青木博文, 中込忠男, 西澤淳: 電炉広幅平鋼及び電炬厚鋼板 (SM490A)を用いた柱・梁接合部の実験，鋼構造論文集，第 1 巻 4 号， pp.127 157, 1994.12

14）立山英二, 湯田誠，田中利幸：スカラップを有する実大鉄骨梁の単調お 上び絽返し加力下における力学的特性と破壊性状に関する研究, 鋼構造 論文集，第3巻10号, pp.49 60, 1996.6

15) 田中淳夫, 増田浩志, 高木大, 久田哲彰：鋼構 造梁端混用接合部の力学 性状に関する研究, 日本建案学会構造系論文集, 第484号, pp.121 $130,1996.6$

16）山下英明，甲津功夫，佐野直樹：銅構造混用接合を用いた柱梁接合部の 力学特性, 鋼構造年次論文報告集, 第4巻, pp.81 88, 1996.11

17) 寺田岳彦, 矢部喜堂, 真瀬伸治, 坂本真一, 宇野寿郎：動的荷重下にお ける鉄骨柱梁接合部の力学的挙動に関する実験的研究, 日本建築学会構 造系論文集, 第492号, pp.121 - 129, 1997.2

18）社団法人日本溶接協会：建築鉄骨の地震被害と鋼材セミナー テキスト。 第5章, pp.125 158, 1997.6

19）日本建築学会近畿支部鉄骨構造部会：通しタイアフラム形式で角形鋼管 に接合されるH形鋼梁の塑性変形能力に関する実大実験 報告書, 1997.7

20) 中込忠男, 藤田哲也, 南圭祐, 李建, 村井正敏 : 柱梁溶接接合部におけ るノンスカラップ工法梁端ディテールに関する実験的研究, 日本建築学 会構造系論文集，第498号，pp.145～151，1997.8

21) 中込忠男, 山田丈富, 中野秀二, 岡希光, 的場耕, 村井正敏：高速載荷 による柱梁溶接接合部の力学的性能に関する実験的研究, 日本建築学会 構造系論文集，第499号，pp.115～122，1997.9

22) 會田和広, 中込忠男, 山田丈富, 村井正敏, 中野秀二, 的場耕：60キ口 級高性能鋼を用いた柱梁溶接接合部の力学的性能に関する実験的研究 その1〜その2, 日本建築学会大会学術講演梗概集, C1，pp.391一 $394,1997.9$

23) 土井義則, 田中清, 藤原敏夫, 佐々木聡, 米山真一朗, 寺岡勝, 森田耕 次: 冷間成形角形鋼 管柱-H形鋼梁接合部の耐震性能に及ほす接合部詳細 の影響に関する実験的研究 その1〜その2, 日本建築学会大会学術講演 梗概集, C1, pp.419 422, 1997.9

24) 増田浩志, 田中淳夫, 鐵鋼：鋼構造 梁端混用接 合部の力学性能に関する 実験的研究，日本建築学会構造系論文集，第509号，pp.151 158, 1998.7

25) 宇佐美徹, 金子洋文: スカラップとウェブ接合形式が梁の塑性変形能力 に及ほ寸影響について, 日本建築学会大会学術講演梗概集, C1, pp 353 -354, 1998.9

26）的場耕，中込忠男，山田丈富, 村井正敏, 會田和広：ノンスカラップ工 法を用いた柱梁溶接接合部の変形能力に関する実験的研究 その1〜その 2 , 日本建築学会大会学術講演梗概集， C1, pp.355～358，1998.9

27) 阿部洋, 田中輝明，薮文成，江野口正光，金子洋文，梅国章：柱梁接合 部の変形性能に及ほす梁及び仕口製作方法の影響 その1〜その2, 日本 建築学会大会学術講演梗概集, C1, pp.365 368, 1998.9

28）白井嘉行, 中込忠男, 村上武夫，青木博文，的場耕，會田和広，高橋英 二:通しタイアフラム形状が柱梁溶接接合部の変形能力に及ほす影響に 関する実験的研究, 日本建築学会大会学術講演梗概集, C1, pp.377 $378,1998.9$

29) 安田聡, 泉満, 成原弘之: 箱形断面柱内ダイアフラム形式柱梁接合部の 実大実験，日本建築学会大会学術講演梗概集，C1，pp.395～396，1998.9

30）森田耕次ほか14名：低靬性鋼による柱梁接合部の破断性状 その1〜その 6 , 日本建築学会大会学術講演梗概集, C1, pp.407 418, 1998.9

31）秋山宏，山田哲，松本由香，松岡三郎，小倉桂治，北村春幸：実大振動 台契験による柱梁接合部の破壊性状に関する研究, 日本建築学会構造系 論文集, 第512号, pp.165 172, 1998.10

32) Ben Kato : Deformation Capacity of Steel Structures, Journal of Constructural Steel Research, Vol.17 Nos 1-2, pp.33-94, 1990

33）藤村啓介, 山崎真司：鋼構造梁部材のエネルギー吸収量と梁端接合部の 必要耐力，日本建築学会大会学術講演梗概集，C1，pp.195～916，1999.9

34) 日本建築学会：鋼構造限界状態設計指針・同解説, pp.44 49, 1998

35) 石川信行，小林泰男，束田幸四郎，前中浩，豊田政男：構造用鋼の変形· 破壊特性に及ほす歪速度の影響，鋼構造年次論文報告集，第4巻，pp 113 $\sim 120,1996.11$

36) P.E.Bennet, G.M.Sinclair : Parameter Representation of Low-Temperature Yield Behavior of Body-Centered Cubic Transition Metals, Transactions of the ASME, pp. $518 \sim 524,1966.6$

注 1)

有孔引張材が最大耐力に達したときの最小断面位置の平均軸方向 応力度は引張強さ以上となるが,これは材軸方向の断面積変化に伴 う応力集中のためであると考えられる。梁端接合部においても，ウエ ブ接合にHTBが用いられている場合あるいは柱材が角型鋼管の場合 等で, ウェブ接合部で伝達されるモーメントが梁母材ウェブで伝達 されるモーメントより小さい場合には，有孔引張材接合部の場合と 同様，応力集中により，材端フランジ断面軸方向平均応力度の最大 值は応力集中が無い場合より上昇することが予想される。ここで対 象としている応力集中は, 切欠先端部に生じる様な局所的な応力集
中とは異なり，部材断面あるいは接合法に係わる巨視的な意味での 応力集中である。

注 2)

梁フランジ又はダイアフラムに破断が生じていない試験体で，局 部座屈による耐力低下，柱部材破断あるいは実験の都合により破断 に至らずに実験を終了している試験体.

注 3)

柱材の降伏点の変化が $ろ$ 及ほす影響は小さい。ここで検討して いる試験体について，降伏点を $1.1 \mathrm{~F} \sim 1.5 \mathrm{~F}$ の範囲で変えたことによ る $\beta$ の変化は $0.3 \%$ 以下である.

\section{付録 1}

$\mathrm{M}_{\mathrm{w}}$ はウェブの接合法および柱断面形状に応じて，以下の方法に より算定する。（文献34)と同一の記号については, 説明を省略す る. )

1) ウェブ接合が溶接接合の場合

a) 柱がH形断面材または円形鋼管材のとき

$\mathbf{M}_{\mathrm{w}}=\left\{\mathrm{t}_{\mathrm{w}}\left(\mathrm{H}-2 \mathrm{t}_{\mathrm{f}}-2 \mathrm{~S}_{\mathrm{r}}\right)^{2} \sigma_{\mathrm{uw}}\right\} / 4$

$\sigma_{\text {uw }}$ : ウェブ材の引張強さ

b) 柱が箱形断面材のとき

$\mathrm{M}_{\mathrm{w}}=\mathrm{t}_{\mathrm{w}}\left(\mathrm{X}-\mathrm{S}_{\mathrm{r}}\right)\left(\mathrm{H}-2 \mathrm{t}_{\mathrm{f}}-\mathrm{X}-\mathrm{S}_{\mathrm{r}}\right) \sigma_{\mathrm{yw}}$

Xは文献34)の(3.71)式により算定する.

2) ウェブ接合が高力ボルト接合の場合

a) 柱がH形断面材または円形鋼管材のとき

$$
M_{w}=\min \left\{{ }_{B} M_{w u 1},{ }_{B} M_{w u 2},{ }_{B} M_{w u 3},{ }_{B} M_{w u 4}\right\}
$$

${ }_{\mathrm{B}} \mathbf{M}_{\mathrm{wu1}} \sim{ }_{\mathrm{B}} \mathrm{M}_{\mathrm{wu} 2}$ は文献34)の(3.74)〜(3.77)式により算定する.

b) 柱が箱形断面材のとき

(付1)式，(付2)式により $\mathrm{M}_{\mathrm{w}}$ を算定し，小さい方を $\mathrm{M}_{\mathrm{w}}$ とする. 付録 2

ただし，(付1)式において $\mathrm{t}_{\mathrm{w}}$ はガセットプレート板厚とする。

パネル耐力比 (Rp)が1末満の試験体をパネルゾーンの降伏が先行 する試験体とする．Rpは，パネルゾーンが降伏するときの梁端モー メントと梁の全塑性モーメントの比で, 図付2(a), (b)に示す十字型, T型試験体について，それぞれ次式で算定する。

$$
\begin{aligned}
& \mathrm{R}_{\mathrm{p}}=\frac{\mathrm{M}_{1}}{\mathrm{M}_{\mathrm{p}}} \\
& \mathrm{M}_{1}=\frac{\sigma_{\mathrm{yp}}}{\sqrt{3}} \cdot \frac{\mathrm{V}_{\mathrm{p}}}{\mathrm{a}} \cdot \frac{1-\lambda}{1-\lambda-\mu} \sqrt{1-\mathrm{n}^{2}}
\end{aligned}
$$

ここで,

$\mathrm{M}_{\mathrm{p}}$ : 梁全塑性モーメント, $\sigma_{\mathrm{yp}}$ ：パネル部鋼材の降伏点

$\mathrm{V}_{\mathrm{p}}=\mathrm{D}_{\mathrm{B}} \mathrm{D}_{\mathrm{C}} \mathrm{t}_{\mathrm{p}} \quad \mathrm{H}$ 形断面柱のとき

$=\frac{16}{9} \mathrm{D}_{\mathrm{B}} \mathrm{D}_{\mathrm{C}} \mathrm{t}_{\mathrm{p}} \quad$ 箱形断面柱のとき

$\mathrm{a}=1$ T型試験体のとき, $\mathrm{a}=2$ 十字型試験体のとき

$\lambda=\frac{D_{\mathrm{C}}}{\ell_{\mathrm{b}}}, \quad \mu=\frac{\mathrm{D}_{\mathrm{B}}}{\ell_{\mathrm{c}}}, \quad \mathrm{n}=\frac{\sigma_{\mathrm{c}}}{\sigma_{\mathrm{yp}}}$,

$t_{p}$ : パネル部板厚, $\sigma_{c}$ : パネル部軸方向平均応力度

$\mathrm{X}$ 型試験体の場合は十字型試験体の場合と同様な式で計算する。 ただしn=0とする。

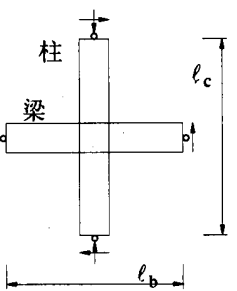

(a) 十字型

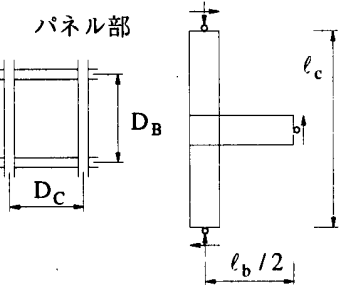

(b) T型
図付1 試験体各部長さ 